\title{
De paradoxale gezondheidseffecten van arbeid : van gezondheidsbedreiging naar gezondheidsbevordering
}

Citation for published version (APA):

Nijhuis, F. (1995). De paradoxale gezondheidseffecten van arbeid : van gezondheidsbedreiging naar gezondheidsbevordering. Maastricht University. https://doi.org/10.26481/spe.19950428fn

Document status and date:

Published: 28/04/1995

DOI:

10.26481/spe.19950428fn

Document Version:

Publisher's PDF, also known as Version of record

\section{Please check the document version of this publication:}

- A submitted manuscript is the version of the article upon submission and before peer-review. There can be important differences between the submitted version and the official published version of record.

People interested in the research are advised to contact the author for the final version of the publication, or visit the DOI to the publisher's website.

- The final author version and the galley proof are versions of the publication after peer review.

- The final published version features the final layout of the paper including the volume, issue and page numbers.

Link to publication

\footnotetext{
General rights rights.

- You may freely distribute the URL identifying the publication in the public portal. please follow below link for the End User Agreement:

www.umlib.nl/taverne-license

Take down policy

If you believe that this document breaches copyright please contact us at:

repository@maastrichtuniversity.nl

providing details and we will investigate your claim.
}

Copyright and moral rights for the publications made accessible in the public portal are retained by the authors and/or other copyright owners and it is a condition of accessing publications that users recognise and abide by the legal requirements associated with these

- Users may download and print one copy of any publication from the public portal for the purpose of private study or research.

- You may not further distribute the material or use it for any profit-making activity or commercial gain

If the publication is distributed under the terms of Article $25 \mathrm{fa}$ of the Dutch Copyright Act, indicated by the "Taverne" license above, 
Universiteitsbibliotheek

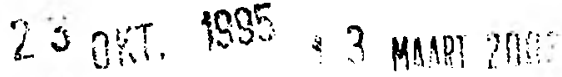

25 OKT. 1996

' 4 MEI 1997

02 บ6. 1397

-8 J!1! 1999
Rijksuniversiteit Limburg

Postbus 616

6200 MD Maastricht

Gelieve deze publicatie tijdig te refourneren of (telefonisch) verlen. ging van de vitleentermijn aan vragen

11 1KN ?ח?0

$24 j u 1 ! \cdots \cdots$$$
\text { viagen }
$$

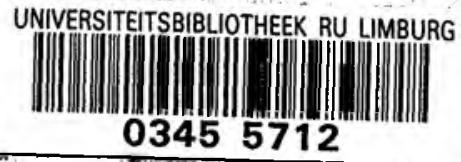




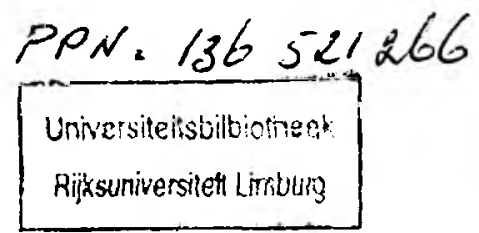




\section{MIJNHEER DE RECTOR MAGNIFICUS, DAMES EN HEREN,}

Maastricht heeft in haar historie een nationale en internationale faam ontwikkeld op het gebied van arbeid en gezondheid. Zo werd reeds in 1887 een parlementaire enquête gehouden naar de toestand van de arbeidsklasse. Deze parlementaire enquete geeft een beeld van de gezondheid en het welzijn van de arbeidende bevolking in drie steden: Tilburg, Amsterdam en Maastricht. Ten aanzien van Maastricht komt in deze enquete naar voren, dat vrouwen en kinderen dertig tot veertig uur aan een stuk in een fabriek werkten, mannen soms dood op hun werk neervielen, armoede, honger en ziekte het leven bijna ondragelijk maakten'). Deze wantoestanden waren ook internationaal bekend. Dit blijkt uit het feit dat de Maastrichtse arbeidsomstandigheden in de glasindustrie op de agenda prijkte van het internationale glasbewerkerscongres in Londen in $1896^{2}$. Gelukkig behoren deze toestanden tot de verleden tijd.

Desondanks blijft het thema Arbeid en Gezondheid actueel. In de afgelopen jaren is de thematiek rond Arbeid en Gezondheid prominent in de media aanwezig geweest. Helaas richt de aandacht zich daarbij vooral op de sociale wetgeving, de uitvoering van de sociale wetgeving, het mogelijke misbruik daarvan en de bezuinigingen daarop. De invloed van de sociale wetgeving op het al dan niet ziekmelden is daarbij van meer belang dan de aard van de ziekte of aandoening.

Daarnaast wordt ook aandacht gericht op factoren in de arbeidssituatie, dis kunnen leiden tot ziekte, burnout of overspanning. Het concept "stress' wordt hierbij een sleutelbegrip.

In de arbeidsenquete van 1887 wordt vooral de fysieke belasting genoemd, die veelal zo ernstig is, dat zij resulteert in een relatief hoge sterfte op jonge leeftijd. Dergelijke extreme vormen van fysieke belasting zijn sinds die tijd] afgenomen, andere vormen van belasting zijn daarentegen sterk toegenomen.

Op dit moment is de ongelijke verdeling van de arbeid een van de belangrijkste problemen. Een steeds kleiner deel van de bevolking werkt, terwijl een steeds groter gedeelte uitgesloten is van de mogelijkheid om te werken. Voor de werkenden betekent dit een hoge werkbelasting en een hoge arbeidsproductiviteit, terwijl de niet-werkenden niet in staat worden gesteld om hun aanwezige arbeidscapaciteit te benutten. In deze drie kwartier zal ik deze tegenstelling, die meestal beschreven wordt vanuit economisch perspectief en vanuit de betaalbaarheid van het sociale stelsel, behandelen vanuit arbeidsgezondheidkundig perspectief, vanuit de optiek van gezondheid en welzijn van de werkenden en de niet-werkenden. Hierbij zal ik mij concen- 
treren op de Nederlandse situatie, omdat de wijze waarop de arbeid gestructureerd is en waarop de sociale zekerheid voor werkenden en niet-werkenden geregeld is, mede van invloed is op de relatie tussen werk en gezondheid. Op basis van deze analyse zal ik aangeven welke mogelijkheden er zijn voor beleid, gericht op de bevordering van de gezondheid en het welzijn van werkenden. Alvorens echter over te gaan op de specifieke belasting die ontstaat in de arbeidssituatie of door het niet kunnen benutten van de arbeidscapaciteit, zal ik een schets geven van de huidige positie van beide groepen.

\section{ONTWMKKELINGEN IN ARBED EN GEZONDHEM}

\section{Ontwikkelingen in de arbeidssituatie}

De ruime aandacht voor de mogelijk negatieve gezondheidseffecten van arbeid, zoals: fysieke klachten, overspanning en burnout lijken erop te wijzen dat de kwaliteit van de arbeid, voorzover deze van invloed is op gezondheid en welzijn van werknemers, de afgelopen jaren steeds slechter aan het worden is. Dit is echter maar ten dele het geval. Op een aantal punten is de kwaliteit van de arbeid opmerkelijk gestegen.

Tabel 1. Trends in kwaliteit van de arbeid (CBS)

\begin{tabular}{|l|c|l|l|l|l|l|l|l|l|l|}
\hline & $\begin{array}{l}\text { Ploegen- } \\
\text { dienst \% }\end{array}$ & $\begin{array}{l}\text { Lawaai } \\
\text { op het } \\
\text { werk }\end{array}$ & $\begin{array}{l}\text { Vuil } \\
\text { werk }\end{array}$ & $\begin{array}{l}\text { Stank } \\
\text { op het } \\
\text { werk }\end{array}$ & $\begin{array}{l}\text { Gevaar- } \\
\text { lijk } \\
\text { werk }\end{array}$ & $\begin{array}{l}\text { Zwaar } \\
\text { werk }\end{array}$ & $\begin{array}{l}\text { Hoog } \\
\text { tempo }\end{array}$ & $\begin{array}{l}\text { Eento- } \\
\text { nig } \\
\text { werk }\end{array}$ & $\begin{array}{l}\text { Promo- } \\
\text { tiemo- } \\
\text { gelijk- } \\
\text { heden }\end{array}$ & $\begin{array}{l}\text { Plezier } \\
\text { in het } \\
\text { werk }\end{array}$ \\
\hline 1974 & 9 & 26 & 28 & & & & & & & \\
77 & 10 & 29 & 22 & 12 & 12 & 21 & 39 & 13 & & \\
\hline 1980 & 10 & 25 & 30 & 13 & 11 & 22 & 37 & 12 & 34 & 77 \\
83 & 12 & 25 & 27 & 10 & 10 & 23 & 45 & 12 & 28 & 77 \\
86 & 11 & 25 & 27 & 10 & 9 & 26 & 50 & 11 & 33 & 77 \\
89 & 11 & 29 & 28 & 13 & 8 & 24 & 53 & 8 & 29 & 79 \\
\hline 1990 & 11 & 27 & 29 & 11 & 9 & 24 & 51 & 9 & 33 & 79 \\
91 & 9 & 28 & 28 & 12 & 7 & 24 & 54 & 6 & 31 & 82 \\
92 & 9 & 26 & 27 & 11 & 7 & 25 & 55 & 8 & 33 & 82 \\
93 & 9 & 27 & 26 & 11 & 8 & 26 & 56 & 8 & 29 & 82 \\
\hline
\end{tabular}

Uit dit overzicht van het Centraal Bureau voor de Statistiek ${ }^{3)}$ blijkt dat het aantal werknemers dat gevaarlijk werk verrichtte in de afgelopen vijftien tot twintig jaar, gedaald is van $12 \%$ naar $8 \%$. Ook het aantal werknemers dat eentonig werk verricht, is in deze periode met een ongeveer gelijk percenta- 
ge gedaald. Een aantal andere factoren, zoals het werken in ploegendienst, het blootgesteld zijn aan lawaai en de promotie-mogelijkheden in de werksituatie, zijn over deze periode relatief constant gebleven.

Daarentegen is het aantal werknemers dat geconfronteerd wordt met een hoog arbeidstempo, over deze periode wel fors gestegen. Het percentage werknemers dat van mening is dat zij met een hoog arbeidstempo moet werken is over een periode van 15 jaar met ongeveer $40 \%$ gestegen.

Over het geheel genomen kan geconstateerd worden dat de fysieke belasting over de afgelopen jaren gelijk gebleven is, maar dat het werken met een hoog arbeidstempo, of een hoge werkdruk in die tijd aanmerkelijk is toegenomen. In zijn totaliteit blijken werknemers in het algemeen meer plezier te hebben in de eigen werksituatie.

Deze gegevens bieden echter geen verklaring voor de toegenomen aandacht voor de relatie tussen arbeid en gezondheid en evenmin verklaren deze bevindingen de vaak genoemde toename van het aantal arbeidsongeschiktheidsgevallen.

\section{Ontwikkelingen in de gezondheid van werkenden en niet-werkenden}

Naast ontwikkelingen in de arbeidssituatie, waar de genoemde belastende factoren deel van uitmaken, zijn er ook ontwikkelingen te constateren met betrekking tot het voorkomen van gezondheidsklachten en ziekten bij werknemers.

Op basis van de statistische gegevens, zoals deze in het verleden door de SVR en de GMD verzameld werden, is het mogelijk om te analyseren of er wijzigingen opgetreden zijn in de diagnoses van de verzuimgevallen. Een dergelijke verschuiving in diagnostiek zou informatie kunnen geven over mogelijke veranderingen in de arbeidsbelasting. De belangrijkste verschuiving die in de afgelopen jaren geconstateerd is met betrekking tot het voorkomen van klachten en aandoeningen in de diagnosegroep "psychische stoornissen"4).

Duidelijk is dat de diagnosegroep "psychische stoomissen" snel gegroeid is. $\mathrm{Bij}$ de nieuwe WAO-gevallen is "psychische stoornissen" de belangrijkste diagnosecategorie geworden. Rond 1980 werd ongeveer een kwart van de nieuwe gevallen in de WAO gediagnosticeerd als arbeidsongeschikt op psychische gronden, begin jaren negentig is het aantal nieuwe WAO-gevallen in deze categorie $\pm 35 \%$. 
soms gewekt wordt, is dat de WAO een gemakkelijke weg is geweest voor organisaties en bedrijven om hun werknemersbestand te saneren en daarmee zou de WAO feitelijk een alternatieve WW-uitkering zijn geworden.

Verschillende onderzoeken over deze periode hebben aangetoond dat de gezondheid van de arbeidsongeschikten sterk verschillend is van de gezondheid van werklozen ${ }^{5)}$. Arbeidsongeschikten hebben een duidelijk slechtere gezondheid en daarmee een beperktere verdiencapaciteit dan werkenden en werklozen. Arbeidsongeschiktheid onderscheidt zich van werkloosheid door de verminderde arbeids- en verdiencapaciteit van arbeidsongeschikten in vergelijking met werklozen. De sociale zekerheidswetgeving, en in het bijzonder de WAO, heeft het bedrijven en organisaties mogelijk gemaakt om op een maatschappelijk aanvaarde wijze te selecteren tussen gezonde en minder gezonde werknemers ${ }^{6}$.

Het gegeven dat werknemers met een psychische aandoening momentee moeilijker dan in het verleden terug kunnen keren in het arbeidsproces, pas in deze ontwikkeling.

Deze vorm van selectie op gezondheid van werknemers heeft geleid tot eer structurele wijziging in de arbeidende populatie, met als gevolg dat de gezondheid van de huidige werknemers beter is dan ooit te voren. Aangezien het productieproces zich op deze gezonde populatie heeft gericht, kan het productiesysteem uitgaan van een maximale inzet, een hoog arbeidstempo en een gering uitvalsrisico. Met als gevolg dat diegenen die een handicap of aandoening hebben, steeds moeilijker ingepast kunnen worden in het arbeidsproces. De toegang van (partieel) gehandicapten tot de arbeidsmarkt wordt daardoor sterk bemoeilijkt. De sociale wetgeving in Nederland heeft geleid tot een maatschappelijk productieproces dat in zijn totaliteit als een zgn. "lean" productieproces gezien kan worden. Dit productieproces wordt gekenmerkt door een zo slank mogelijke organisatie, met zo weinig mogelijk werknemers, met zo weinig mogelijke voorraden en met behoud van zoveel mogelijk interne flexibiliteit. De consequentie hiervan is dat slechts die werknemers die aan deze moderne productie-eisen kunnen beantwoorden, een kans maken op een vaste arbeidsplek. In analogie met de inzet van werknemers in een "lean"-productieproces kan geconstateerd worden dat in Nederland vooral de gezonde, productieve mensen werkzaam zijn.

Op basis van deze bevindingen zijn de volgende conclusies te trekken:

1. De werkdruk wordt door werknemers gezien als een in belang toenemende stressor in de werksituatie.

2. Het aantal werknemers met een psychische aandoening in het ziektewetjaar stijgt niet; de kans voor de werknemers met een psychische 
Op basis van figuur $1^{3)}$ kan geconstateerd worden dat het aantal arbeidsongeschiktheidsuitkeringen over een periode van 25 jaar vrij snel gestegen is. In plaats van de bij aanvang verwachte 150.000 à 200.000 uitkeringsgerechtigden, bedroeg eind 1994 het aantal uitkeringsgerechtigden in feite zo'n 900.000. De op deze wijze gepresenteerde stijging in absolute aantallen is echter misleidend. Bij het beschrijven van het aantal WAO-uitkeringen dienen veranderingen in de arbeidspopulatie verdisconteerd te worden. Indien het aantal werknemers toeneemt zal, bij een gelijkblijvend WAOrisico, eveneens het aantal WAO-uitkeringen toenemen. Dus zoals het aantal verkeersongevallen slechts relevant is, indien gecorrigeerd wordt voor de stijging in het aantal verreden kilometers en het aantal verkeersdeelnemers, zal het aantal arbeidsongeschiktheidsuitkeringen gecorrigeerd dienen te worden voor verschillen in het aantal verzekerden. Met deze correctie ontstaat een ietwat genuanceerder beeld van de stijging in het aantal WAOgevallen (figur 2$)^{3}$.

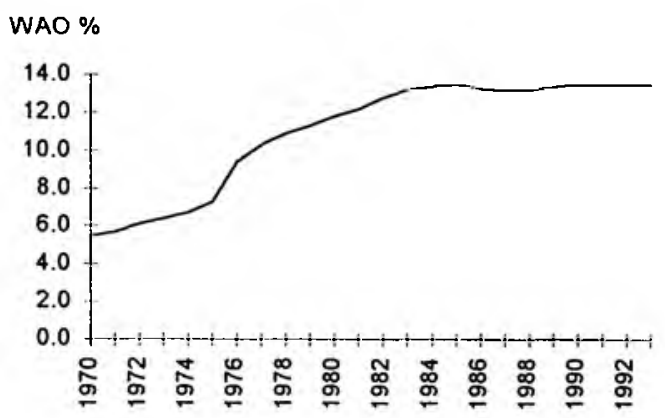

Figuur 2. WAO-toetreding gerelateerd aan aantal WAO-verzekerden (1970-1993)

We constateren een snelle stijging van het aantal arbeidsongeschikten over de eerste tien jaar van de invoering van de arbeidsongeschiktheidswetgeving. Vanaf 1980 wordt het aantal uitkeringsgerechtigden relatief stabiel.

De ontwikkeling van het aantal uitkeringsgerechtigden over deze periode heeft de afgelopen jaren tot een brede discussie geleid, uitmondend in een Parlementaire Enquete over de uitvoering van de sociale zekerheid. De indruk die in de discussie over de stijging van het aantal WAO-toetredingen 
De incidentie van de diagnosegroep "psychische aandoeningen" bij de ziekmelding is echter niet gestegen. Per 100 werknemers waren er rond 1970 5,5 ziektevallen vanwege de diagnosegroep "psychische aandoeningen" en 110 ziektevallen vanwege overige aandoeningen. (Gemiddeld kan men vaker dan één keer per jaar ziek zijn.) In 1990 is het aantal gevallen in de diagnosegroep "psychische aandoeningen" licht gedaald tot 5,2 per 100 werknemers, terwijl er 117 ziekmeldingen waren voor overige aandoeningen. Relatief is de incidentie van het aantal gevallen in de diagnosegroep "psychische stoomissen" bij ziekmelding afgenomen.

Deze twee tendensen lijken moeilijk met elkaar te rijmen. Het feit dat met name bij nieuwe WAO-gevallen de diagnosegroep psychische aandoeningen sterk gegroeid is, zonder dat de incidentie van verzuimgevallen bij werknemers in deze diagnosegroep gestegen is, kan slechts verklaard worden door een verminderde herstel- of herintredekans. Blijkbaar is het steeds moeilijker geworden om met een psychische aandoening terug te keren naar de arbeidsplek. Een veronderstelling die bevestigd wordt door een stijging van de

( gemiddelde verzuimduur wegens psychische aandoeningen. In 1970 was de gemiddelde verzuimduur van een ziektegeval in de diagnose-categorie "psychische aandoeningen" 55 dagen, terwijl in 1990 een verzuim wegens psychische aandoeningen gemiddeld 101 dagen duurt. Het hebben van een psychische aandoening lijkt meer dan in het verleden te leiden tot uitstoting uit het arbeidsproces.

Een andere indicator, betreffende de gezondheidstoestand van de Nederlandse werknemer, is de ontwikkeling in het totaal aantal WAO-gevallen.

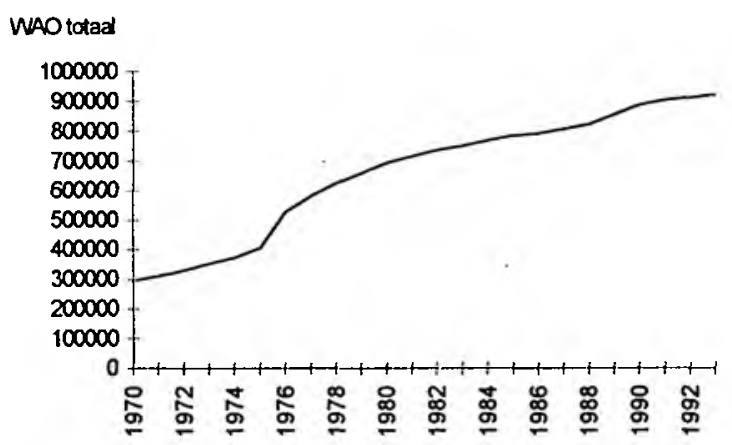

Figuur 1. Ontwikkeling aantal WAO-uitkeringsgerechtigden 1970 - 1993 
aandoening om binnen het ziektewetjaar terug te keren in het arbeidsproces is afgenomen.

3. De sociale zekerheidswetgeving heeft arbeidsorganisaties de mogelijkheid geboden om een selectie te maken van gezonde werknemers, die in staat zijn om een maximale arbeidsinspanning te leveren.

\section{BELASTING TEN GEVOLGE VAN NIET-WERKEN}

\section{Gezonde arbeid}

De arbeid is niet, zoals wellicht uit het voorgaande geconcludeerd zou kunnen worden, uitsluitend een risicofactor voor de gezondheid. Het verrichten van arbeid kan de gezondheid en het welzijn van de werknemers ook positief beïnvloeden.

Positieve elementen die ontleend worden aan het werk en aan werken, zijn onder meer:

* door middel van de arbeid verwerft iemand een maatschappelijke positie,

* door arbeid wordt een inkomen verworven,

* het inkomen geeft sociale en maatschappelijke zekerheid,

* het hebben van werk biedt een positief toekomstperspectief,

* het verrichten van arbeid biedt mogelijkheden tot zelfontplooiing door o.a. het opdoen van nieuwe vaardigheden en nieuwe kennis,

* arbeid levert sociale contacten op,

* arbeid geeft een zinvolle invulling van de tijd, waardoor zowel werkals vrije dagen een bepaalde extra-betekenis verwerven.

Met uitzondering van het laatste punt, is het opvallend dat de positieve kenmerken van de arbeid vooral betrekking hebben op het verrichten van arbeid-an-sich. De genoemde positieve aspecten hebben een algemene en generieke geldigheid, onafhankelijk van de aard van de daadwerkelijk verrichte arbeid. Op basis hiervan kan een onderscheid gemaakt worden tussen de positieve en negatieve gevolgen van de arbeid. De positieve gevolgen hebben betrekking op de arbeid zelf, op het hebben van werk als zodanig, terwijl de negatieve gevolgen betrekking hebben op specifieke belasting in de concrete werksituatie. Vanuit dit gezichtspunt is het dan ook niet vreemd dat positieve en negatieve gevolgen tegelijk aanwezig kunnen zijn in een arbeidssituatie, zonder dat deze elkaar opheffen of aan elkaar gerelateerd behoeven te zijn. Vandaar dat ik hier in eerste instantie aandacht zal geven aan de belasting die kan onistaan door het niet hebben van werk, om in 
tweede instantie een tweetal potentieel belastende arbeidsfactoren te beschrijven, die typerend zijn voor de wijze waarop op dit moment de productie georganiseerd is en die ook in de naaste toekomst een steeds belangrijkere rol zullen spelen, zowel in het behoud van de arbeidsplek als in de vorm van stressor in de arbeidssituatie, namelijk: werkdruk en flexibiliteit.

De positieve waardering van de arbeid komt het meest duidelijk naar voren indien onderscheid gemaakt wordt naar gezondheid en welzijn van werkenden en werklozen.

Onderzoek naar gezondheidsverschillen tussen werkenden en werklozen laat een gedifferentieerd beeld zien. Ten aanzien van de lichamelijke gezondheid worden tegenstrijdige onderzoeksresultaten gerapporteerd, terwijl met betrekking tot welzijn en psychische gezondheid de onderzoeksgegevens elkaar bevestigen ${ }^{5,7,8)}$.

Internationaal wordt in een aantal gevallen gevonden dat werklozen in vergelijking tot werkenden een slechtere gezondheid hebben, blijkend uit ondermeer een hoger aantal gezondheidsklachten, verschil in cardio-vasculaire risicofactoren (systolische bloeddruk, serumcholesterol, HDL), maar ook in hogere mortaliteitsratio's ${ }^{9.10 .11)}$. Nederlands onderzoek bevestigt deze resultaten niet; de conclusie lijkt daarom gerechtvaardigd dat, voorzover het onderzoek gericht is geweest op de lichamelijke gezondheid, een relatie tussen een slechtere fysieke gezondheid en werkloosheid niet direct aantoonbaar is. In een recent door ons uitgevoerd onderzoek ${ }^{(2)}$ bleek bijvoorbeeld dat werklozen zich, met betrekking tot de lichamelijke gezondheid nauwelijks onderscheiden van werkenden (tabel 2). Beide groepen verschillen met betrekking tot de lichamelijke gezondheid van arbeidsongeschikten. Dit wijst eens te meer op een selectieve uitstoot van ongezonde werknemers via de WAO.

Tabel 2. Een vergelijking van werkenden, werklozen en arbeidsongeschikten met betrekking tot fysieke gezondheid

\begin{tabular}{|l|c|c|c|}
\hline & $\begin{array}{c}\text { Werkend } \\
(\mathrm{N}=778)\end{array}$ & $\begin{array}{c}\text { Werkloos } \\
(\mathrm{N}=49)\end{array}$ & $\begin{array}{c}\text { Arbeidsongeschikt } \\
(\mathrm{N}=100)\end{array}$ \\
\hline Algemene gezondheid & 3.96 & 3.82 & $3.17 \quad \mathrm{a})^{* * *}$ \\
\hline Gezondheid in vergelijk met peers & 3.24 & 3.24 & $2.69 \quad \mathrm{a})^{* * *}$ \\
\hline $\begin{array}{l}\text { Gezondheid vergeleken met een jaar } \\
\text { geleden }\end{array}$ & 3.06 & 3.06 & 2.93 \\
\hline Ervaren gezondheidsklachten & 4.67 & 4.68 & $5.40 \quad$ a) \\
\hline
\end{tabular}

a) De arbeidsongeschikten verschillen significant van de werkenden en werklozen 
Met betrekking tot de psychische gezondheid en het geestelijk welbevinden laten de onderzoeksresultaten zien dat het werkloos zijn, samenhangt met een duidelijk verminderd welbevinden (tabel 3).

Tabel 3. Psychische klachten

\begin{tabular}{|c|c|c|c|}
\hline & $\begin{array}{l}\text { Werkend } \\
(\mathrm{N}=778)\end{array}$ & $\begin{array}{l}\text { Werkloos } \\
(N=49)\end{array}$ & $\begin{array}{l}\text { Arbeidsongeschikt } \\
\qquad(N=100)\end{array}$ \\
\hline Depressie & 20.61 & 24.37 & $23.82 \quad c)^{* * *}$ \\
\hline Angstgevoelens & 4.30 & 6.97 & 5.53 \\
\hline Geestelijke gezondheid & 1.02 & 1.13 & $1.07 \quad c)^{* * *}$ \\
\hline Tevredenheid & 4.37 & 3.82 & $4.11 b)^{* * *}$ \\
\hline Duizeligheidsklachten & 1.21 & 1.27 & 1.34 \\
\hline Nerveuze klachten & 1.26 & 1.31 & 1.38 \\
\hline Slaapklachten & 6.13 & 10.03 & $8.60 \mathrm{c})^{* * * *}$ \\
\hline
\end{tabular}

a) arbeidsongeschikten verschillen van werkenden en werklozen

b) de drie groepen verschillen van elkaar

c) arbeidsongeschikten en werklozen verschillen van werkenden

*** $\quad \mathrm{p} \leq 0.001$

$* * \quad 0.001<\mathrm{p} \leq 0.01$

* $\quad 0.01<\mathrm{p} \leq 0.05$

Het verminderd welbevinden en de verminderde psychische gezondheid van werklozen en in mindere mate van arbeidsongeschikten, gaat samen met het verliezen van sociale contacten en het ervaren van meer levensproblemen (blijkend uit bijvoorbeeld meer financiële beperkingen).

De elkaar tegensprekende bevindingen met betrekking tot de relatie tussen het werkloos-zijn en lichamelijke gezondheidseffecten krijgen meer perspectief vanuit een tweetal gezichtspunten. Op de eerste plaats vindt zoals eerder gesteld, in Nederland een gezondheidsselectie plaats bij de uitstoot van arbeid, met andere woorden, werknemers die vanwege gezondheidsklachten niet meer voldoende kunnen presteren, maken in Nederland een grotere kans om een uitkering te krijgen in het kader van de arbeidsongeschiktheidswetgeving dan in het kader van een werkloosheidsuitkering. In de Nederlandse situatie lijkt dan ook door de sociale wetgeving niet slechts sprake te zijn van een healthy worker effect, maar ook van een healthy unemployed effect ${ }^{13,14)}$.

Op de tweede plaats gaat werkloosheid in een groot aantal andere landen gepaard met een aanzienlijk inkomensverlies. Naarmate deze terugval in 
inkomen groter is, zal de werkloosheidssituatie niet uitsluitend meer gekenmerkt worden door het niet-hebben van arbeid, maar tevens door armoede, slechte wooncondities, verlies aan sociale status etc. De geconstateerde verminderde gezondheid is dan niet alleen gerelateerd aan het geen werk hebben, maar tegelijkertijd aan de sociaal-economische gevolgen van het werkloos zijn ${ }^{14)}$.

De positieve welzijns- en gezondheidsbevorderende aspecten van arbeid hebben vooral te maken met het hebben van arbeid en de zinverlening door de arbeid. De negatieve gezondheids- en welzijnseffecten zijn hier het spiegelbeeld van; deze negatieve effecten worden versterkt door de financiële en maatschappelijke beperkingen die het niet-werken met zich meebrengt.

Vanuit het perspectief van arbeid en gezondheid betekent dit, dat mensen zoveel mogelijk de kans dienen te krijgen om deel te nemen aan het arbeidsproces onder de gelijktijdige conditie dat de arbeidssituatie zodanig is dat de gezondheid en het welzijn niet geschaad wordt.

\section{ONTWIKKELING VAN DE BELASTING IN DE MODERNE WERKSITUATIE}

Bij de beschrijving van ontwikkelingen in de arbeidssituatie heb ik zojuist aangegeven dat de moderne ontwikkelingen in de arbeidsomstandigheden, in de arbeidsverhoudingen, in de arbeidsvoorwaarden en in de arbeidsinhoud niet automatisch leiden tot een bevordering van de gezondheid en het welzijn van de werknemer.

De huidige Nederlandse arbeidssituatie wordt gekenmerkt door het gegeven dat slechts die arbeidscapaciteit benut wordt, die een optimale bijdrage levert aan de gewenste productie. Moderne productie-organisaties leveren kwalitatief zeer goede producten, die binnen een zeer nauw omschreven tijdseenheid gemaakt moet worden en die beantwoorden aan de specifieke eisen die de client stelt. Dit impliceert dat in mindere mate op voorraad gewerkt wordt, en meer en meer gewerkt wordt met specifieke product-beschrijvingen en met een zeer strikte productieplanning.

Organisaties trachten dit te realiseren door flexibel om te gaan met hun pel soneelsleden en het creëren van een hoge arbeidsproductiviteit en met ee hoge werkdruk. Deze organisatiewijze heeft in de organisatie-literatuur d benaming gekregen van "lean"15,16).

Een dergelijke wijze van productie brengt zoals eerder gesteld, twee vormen van belasting, twee stressoren met zich mee die van grote invloed kunnen 
zijn op gezondheid en welzijn van de werknemer, te weten: werkdruk flexibiliteit.

\section{WERKDRUK}

Zoals in de eerste tabel reeds te zien was, is de grootste ervaren verandering van de belasting in de werksituatie in Nederland het arbeidstempo, de druk waaronder gewerkt moet worden.

De uitkomsten van een grootschalig krantelezer-onderzoek ${ }^{17}$, waarbij aan de lezers gevraagd is om een uitgebreide enquete in te vullen m.b.t. stressoren in de werksituatie en de ervaren gezondheids- en welzijnsklachten, tonen eveneens dat een op de vier respondenten zijn of haar werk als fysiek belastend ervaart, terwijl meer dan $80 \%$ van de respondenten hun werk als mentaal belastend ervaren (tabel 4$)^{(7)}$.

Tabel 4. Stressoren in de arbeidssituatie

\begin{tabular}{|l|c|}
\hline & \% eens \\
\hline werkdruk & 75 \\
werk vereist hard werken & 68 \\
werkt onder tijdsdruk & 30 \\
hoeft niet overdreven veel te doen & \\
\hline mentale belasting & 82 \\
werk vereist voortdurend opletten & 89 \\
moet bij werk veel onthouden & 94 \\
werk vereist grote nauwkeurigheid & \\
\hline fysieke belasting & 28 \\
werk eist veel lichamelijke belasting & \\
\hline
\end{tabular}

Op basis van diverse onderzoeken binnen ons onderzoeksprogramma op hel terrein van arbeid en gezondheid, blijkt de werkdruk een belangrijke voorspeller te zijn van gezondheidsklachten en emotionele uitputting.

Zo blijkt dat bij verplegenden en verzorgenden de werkdruk een sterke samenhang vertoont met burnout en vermoeidheid ${ }^{18}$.

Ook blijkt uit een vragenlijst, afgenomen bij een grote groep werkenden, werkzaam in diverse sectoren, dat de ervaren werkdruk een van de belangrijkste voorspellers van vermoeidheid en burnout is.

Het meest extreme gevolg van de uitputting ten gevolge van een hoge werkdruk is de acute dood. In Japan ${ }^{19)}$ is onderzoek verricht naar oorzaken van Karoshi, ofwel dood ten gevolge van oververmoeidheid. Bij bijna $70 \%$ van de onderzochte Karoshi-slachtoffers was sprake van oververmoeidheid ten gevolge van a) een zeer groot aantal arbeidsuren, b) de aanpassing aan 
nieuwe werkvormen, en c) een tekort aan arbeidskrachten, waardoor de lwezige werknemers extra-activiteiten dienden te verrichten. derzoek van Karasek en Theorel1 ${ }^{20)}$ heeft laten zien dat de mate waarin rkdruk leidt tot gezondheidsklachten mede bepaald wordt door de mogetheden van de werknemer om die werkdruk te beïnvloeden. Een hoge .. rkdruk die gepaard gaat met weinig controle over het werk, met onvoldoende hulpmiddelen, en met een geringe sociale ondersteuning op het werk, blijkt te leiden tot meer gezondheidsklachten, dan een hoge werkdruk die gepaard gaat met veel beïnvloedingsmogelijkheden met betrekking tot het eigen werk. Diegene die onder hoge werkdruk werkt èn tegelijkertijd in staat is om zelf te bepalen hoe hij/zij bepaalde zaken aan moet pakken, om zelf te bepalen wanneer hij/zij bepaalde dingen af moet hebben, om zelf de volgorde van zijn/haar activiteiten te beïnvloeden, om over voldoende hulpmiddel te beschikken, diegene heeft duidelijk een veeleisende en uitdagende taak, een taak die gepaard gaat met groei, met intrinsieke waardering en leermogelijkheden. Een dergelijke taak is wel belastend maar hoeft niet gezondheidsbedreigend te zijn. Dit zijn taken zoals deze door de meeste professionals uitgeoefend worden. Dergelijke taken zijn minder stressvol dan taken die een hoge mate van werkdruk combineren met geringe mogelijkheden om deze werkdruk te beïnvloeden, met onvoldoende hulpmiddelen en met de onmogelijkheid om zich zonodig (even) aan de werkzaamheden te ${ }^{-\cdots}$ trekken.

noderne productieprocessen ontstaat de overbelasting juist door de comatie van deze beide stresserende tendenties (een hoge werkdruk en weinig elmogelijkheden). Intensivering van het productieproces gaat veelal gepaard met een verhoogde externe controle op de uitvoering. Met name de moderne informatiesystemen maken het mogelijk om in elke vorm van productie een productielijn te starten met geringe voorraden, minimale hulpmiddelen, minimale werktijden en directe kwaliteitscontrole. Bij deze wijze van produceren ontstaat een extra-belasting doordat werknemers geacht worden een hoge mate van zelf-controle te hebben binnen het productieproces, terwijl de controle van werknemers over de randvoorwaarden van het productieproces afneemt. Werknemers worden verantwoordelijk gesteld voor hun handelen, terwijl zij deze verantwoordelijkheid niet kunnen waarma$\operatorname{ken}^{21)}$. Hierdoor wordt een overbelastingssituatie gecreëerd die leidt tot gezondheidsklachten, vermoeidheid en uitputting.

Een dergelijk productiesysteem eist een maximale inspanning van werknemers, waardoor de mogelijkheden om met bepaalde gezondheidsklachten of met bepaalde beperkingen, in de werksituatie te functioneren belemmerd worden en meer nog de mogelijkheden om met een beperkte arbeidscapaciteit terug te keren in het arbeidsproces. 


\section{FI EXIBUITEIT}

1 tweede belastende factor waardoor de arbeid in onze tijd gekenmerkt $r d t$, is de groeiende flexibiliteit ${ }^{22)}$. Op dit moment werken $\pm 20 \%$ van de werknemers op de een of andere manier onder een flexibel contract. Gedacht moet daarbij worden aan oproepcontracten, nul-uren contracten, uitzendkrachten, tijdelijke aanstellingen etc. Atkinson ${ }^{23)}$ heeft reeds eerder aangegeven dat het personeel in organisaties opgedeeld kan worden in een kern-groep en in een rand-groep. De kern-groep wordt gevormd door werknemers, waarin door het bedrijf geïnvesteerd wordt, die multi-inzetbaar zijn, die een hoge mate van commitment hebben met het bedrijf, terwijl de randgroep eenvoudige, relatief ongeschoolde arbeid uitvoert, gemakkelijk vervangbaar is, terwijl bovendien de omvang van deze randgroep fluctueert al naar gelang de omvang van de orderportefeuille.

Uit een onderzoek onder Belgische werknemers blijkt dat diegenen die onder flexibele arbeidsomstandigheden werken meer gezondheids- en welzijnsklachten hebben dan diegenen die werken onder een niet-flexibel contract (tabel 5) $)^{24)}$.

Tabel 5. Toetsing van verschillen in gezondheid, welzijn en slaapklachten tussen werknemers werkzaam onder een of meer flexibele arbeidsvormen en werknemers zonder flexibel arbeidscontract

\begin{tabular}{|c|c|c|c|c|c|c|}
\hline & \multirow{2}{*}{$\begin{array}{l}\text { Niet flexi- } \\
\text { bel } \\
\text { werkenden }\end{array}$} & \multicolumn{5}{|c|}{ Flexibel werkenden } \\
\hline & & $\begin{array}{l}\text { Tijdelijk } \\
\text { contract }\end{array}$ & $\begin{array}{l}\text { Afroep } \\
\text { contract }\end{array}$ & $\begin{array}{l}\text { Volcon- } \\
\text { tinue } \\
\text { dienst }\end{array}$ & $\begin{array}{l}\text { Onregel- } \\
\text { matige } \\
\text { werkuren }\end{array}$ & $\begin{array}{l}\text { Gecom- } \\
\text { primeerde } \\
\text { werkweek } \\
(>10 \\
\mathrm{u} / \mathrm{pw})\end{array}$ \\
\hline $\begin{array}{l}\text { Aantal gezond- } \\
\text { heidsklachten } \\
\text { m } \\
\text { (sd) } \\
\text { (N) }\end{array}$ & $\begin{array}{c}6.9 \\
(5.3) \\
(125)\end{array}$ & $\begin{array}{l}9.3^{* *} \\
(5.1) \\
(58)\end{array}$ & $\begin{array}{l}8.6^{*} \\
(4.1) \\
(27)\end{array}$ & $\begin{array}{l}8.5^{*} \\
(5.1) \\
(111)\end{array}$ & $\begin{array}{c}9.6^{* * *} \\
(5.1) \\
(161)\end{array}$ & $\begin{array}{c}9.8 * * * \\
(5.2) \\
(84)\end{array}$ \\
\hline $\begin{array}{c}\text { Aantal klachten } \\
\text { m.b.t. welzijn } \\
\text { m } \\
(\mathrm{sd}) \\
(\mathrm{N})\end{array}$ & $\begin{array}{c}6.7 \\
(4.9) \\
(125)\end{array}$ & $\begin{array}{l}9.3^{* *} \\
(5.7) \\
(60)\end{array}$ & $\begin{array}{l}8.3 \\
(5.4) \\
(28)\end{array}$ & $\begin{array}{c}7.7 \\
(5.1) \\
(110)\end{array}$ & $\begin{array}{c}8.8^{* * * *} \\
(5.5) \\
(165)\end{array}$ & $\begin{array}{c}10.0^{* * *} \\
(5.5) \\
(84)\end{array}$ \\
\hline $\begin{array}{c}\text { Slaapkwaliteit } \\
\text { m } \\
\text { (sd) } \\
\text { (N) }\end{array}$ & $\begin{array}{c}6.1 \\
(2.6) \\
(123)\end{array}$ & $\begin{array}{l}4.8^{* *} \\
(2.9) \\
(56)\end{array}$ & $\begin{array}{l}4.4^{* *} \\
(2.7) \\
(26)\end{array}$ & $\begin{array}{l}5.4^{*} \\
(2.9) \\
(110)\end{array}$ & $\begin{array}{c}5.0^{* * *} \\
(2.8) \\
(163)\end{array}$ & $\begin{array}{c}4.6 * * * \\
(2.9) \\
(80)\end{array}$ \\
\hline
\end{tabular}

Dubbelzijdig getoetst; $* \mathrm{p}=<.05 ; * * \mathrm{p}=<.01 ; \mathrm{p} * * *:=<.001$ 
Naarmate de flexibiliteit leidt tot een intensivering van de arbeid, tot een uitbreiding van het aantal gewerkte uren en tot een grotere onregelmatigheid, zijn de gezondheids- en welzijnsklachten groter.

Als voordeel van flexibiliteit wordt vaak gesteld dat de werknemer een grotere vrijheid heeft om zijn werk en vrije tijd naar eigen believen in te vullen. In tegenstelling tot deze verwachtingen, blijkt uit het genoemd onderzoek dat werknemers met zeer flexibele arbeidscontracten, meer problemen hebben met de gewenste invulling van de vrije tijd en dat zij zich bijvoorbeeld minder betrokken voelen bij de opvoeding van de kinderen ${ }^{25}$. Flexibiliteit kan echter ook de gezondheid en het welzijn van werknemers bevorderen. Dit positieve effect treedt vooral op wanneer werknemers hun eigen onregelmatigheid kunnen plannen en beïnvloeden. Ook hier blijkt dat de mate van controle over de arbeidsconditie bepalend is voor het optreden van positieve of negatieve gezondheidseffecten. Met name functieflexibiliteit (rouleren, wisselen van werkzaamheden, multi-inzetbaarheid) blijkt de gezondheid en het welzijn te bevorderen ${ }^{26)}$. Bij functieflexibiliteit kan de flexibiliteit vaak ingevuld worden door de werknemer zelf, of gaat de flexibiliteit gepaard met nieuwe uitdagingen, met het leren van nieuwe vaardigheden, met het vergroten van het aantal vrijheidsgraden in het werk en met een vergroting van de controle over het werk ${ }^{27)}$. In een dergelijk geval is de flexibilisering niet slechts een wijze waarop de organisatie zich aanpast aan wisselingen in de vraag van de afnemers, maar komt de flexibilisering mede voort uit de behoefte om de kwaliteit van de arbeid te verbeteren.

In een aantal meer ideologische getinte studies wordt vaak verondersteld dat de moderne mens een hoge mate van flexibiliteit in de functie positief zou waarderen. Een recente studie laat echter zien dat deze moderne werknemer niet bestaat en dat werknemers nog steeds een vaste werkplek ambiëren en dat de keuze voor tijdelijke arbeid slechts in een bepaalde levensfase bij bepaalde beroepsgroepen plaatsheef ${ }^{28)}$.

\section{VAN GEZONDHEIDSBELASTEND NAAR GEZONDHEDSBEVORDEREND}

toren in de arbeidssituatie worden veelal beschreven vanuit een belassperspectief, gericht op schade die zij toebrengen aan de gezondheid en welzijn van werknemers. In de arbeidssituatie geldt dat de aard en omvang van de gezondheids- en welzijnseffecten van de specifieke arbeidscondities, zoals werkdruk en flexibiliteit, afhankelijk is van de concrete wijze waarop deze specifieke arbeidscondities vorm krijgen. Een hoge werkdruk 
noch een hoge mate van flexibiliteit hoeft niet per definitie negatief te zijn voor het welzijn en de gezondheid van de werknemer, mits de werkdruk en flexibiliteit binnen aanvaardbare grenzen blijft. Een goede maat hiervoor is de rusttijd voldoende herstel biedt voor de gepleegde inspanningen.

hier was mijn beschrijving van factoren in de arbeid en de arbeidssituavooral vanuit het perspectief dat deze factoren een mogelijk schadelijke oed hebben op de gezondheid en het welzijn. Op de eerste plaats heb ik seschreven vanuit de positie van werklozen en arbeidsongeschikten en op weede plaats uitgaande van een tweetal stressoren die typerend zijn voor het moderne Westerse productiesysteem: werkdruk en flexibiliteit. Dergelijk onderzoek, naar factoren die leiden tot vermoeidheids-, gezondheids- en welzijnsklachten, zal ook de komende jaren een belangrijk deel uitmaken van het onderzoek op het gebied van de arbeid en gezondheid.

In de komende jaren zal de nadruk binnen het onderzoek en onderwijs op het gebied van de psychologie van arbeid en gezondheid mijn inziens niet meer vooral gericht zijn op de gezondheids- en welzijnsbedreigende factoren, maar meer op voor de gezondheid en het welzijn positieve factoren in de arbeid en op arbeidsgezondheidkundige interventies, die gericht zijn op de bevordering van gezondheid, veiligheid en welzijn. Het onderzoek zal meer gericht dienen te zijn op de vraag hoe de gezondheid en het welzijn van werknemers bevorderd kan worden en hoe een systematisch gezondheidsbevorderingsbeleid in bedrijven vorm gegeven moet worden.

De belangrijkste reden hiervoor is dat organisaties steeds meer moeten :m.rosteren in de werknemers die deel uitmaken van de kerngroep in de inisatie. Het belang om deze werknemers te behouden en te motiveren igt van organisaties niet uitsluitend meer het beperken van gezondheids:o's, maar vooral het creëren van uitdagende, motiverende taken en een vernoogde zorg voor behoud en bevordering van de gezondheid en het welzijn van werknemers. Daarnaast zal ten gevolge van de verandering in de bevolking het aantal oudere werknemers relatief moeten toenemen. Een dergelijke toename kan slechts gerealiseerd worden, indien door het aanbrengen van verbeteringen in de arbeidssituatie vroegtijdige uitval voorkomen kan worden.

Een voorbeeld van een dergelijk gezondheidsbevorderingprogramma is in de afgelopen jaren vanuit onze onderzoeksgroep "Bedrijfsgezondheidkundige Interventies" uitgevoerd.

Op basis van een grondige analyse van de verzuimgegevens en op basis van een uitgebreide enquete onder de werknemers naar stressoren in de arbeids- 
omstandigheden, in de arbeidsvoorwaarden, in de arbeidsinhoud en in de arbeidsverhoudingen, is een interventieprogramma ontwikkeld, waarbij ondermeer de vergroting van de autonomie van (een deel van) de werknemers en vergroting van de zeggenschap over de eigen arbeid centraal stond. Onderdeel van de interventie was een stress-management programma, bestaande uit

* structurele wijzigingen, zoals verbetering van de participatie-structuur;

* gedragsgerelateerde componenten, zoals een verbetering van de communicatieve en leidinggevende vaardigheden;

* een programma, gericht op de herkenning van stress-gerelateerde klachten bij zichzelf en bij anderen;

* verbetering van de wijze waarop werknemers omgaan met stressoren, met name op plannings- en werkdrukproblemen.

Een kosten-baten analyse van dit uitgevoerde stress-management programma laat zien dat zowel het welzijn en de gezondheid van de werknemers positief beïnvloed is, als dat de totaal uitgegeven gelden aan het interventie-programma in korte tijd terugverdiend zijn, ondermeer door een daling van het verzuim, door verbeterde arbeidsverhoudingen en een verbeterde arbeidsinhoud ${ }^{29)}$.

Enerzijds toont de interventie hoe een uitgebreide analyse van de belastende factoren in de werksituatie, van de gezondheid en het welzijn van de werknemer een goed en noodzakelijk uitgangspunt is voor een gezondheidsbevorderingsprogramma. In een dergelijk programma wordt niet alleen de belasting in de werksituatie verminderd, maar worden ook de vaardigheden van werknemers vergroot en worden de arbeidstaken meer motiverend ingericht.

Anderzijds bewijst een dergelijke interventie eens te meer dat de investeringen in gezondheidsprogramma's reeds op korte termijn geld kunnen opleveren. Het investeren in de gezondheid en welzijn van de werknemer blijkt winstgevend te zijn en deze investeringen vormen een van de meest onderschatte winstgenererende activiteiten in een organisatie.

Bevorderen van gezondheid kan door het verbeteren van de arbeidssituatie, maar ook door het verbeteren van de arbeidsparticipatie-mogelijkheden voor diegenen die om gezondheidsredenen uit het arbeidsproces gestoten zijn. Gezocht moet daarbij worden naar factoren die een herintrede in het arbeidsproces kunnen bevorderen, zowel bij de betrokken arbeidsongeschikte werknemer als bij de bedrijven die voor de werkgelegenheid dienen te zorgen. 
De Nederlandse sociale wetgeving heeft ertoe bijgedragen dat de arbeidsorganisaties op een maatschappelijk aanvaarde wijze een productiesysteem konden inrichten, dat afgestemd is op de meest productieve werknemers, waardoor de functies die geschikt zijn voor werknemers met een beperkte arbeidscapaciteit uit de organisatie verdwenen zijn. Hierdoor is een vicieuze cirkel ontstaan, waardoor bedrijven steeds opnieuw arbeidsongeschiktheid genereren, terwijl bedrijven tegelijkertijd minder gemakkelijk minder valide werknemers kunnen plaatsen.

Dit heeft er eveneens toe geleid dat, voor diegenen die een WAO-uitkering hebben, er te weinig mogelijkheden en incentives zijn om de rest-capaciteit optimaal te benutten. Het bevorderen van de arbeidscapaciteit van arbeidsongeschikten vraagt dan ook om interventies, die gericht zijn op het activeren van zowel bedrijven als werknemers om tot een benutting van de resterende arbeidscapaciteit te komen.

Interventies die vooral gericht zijn op het beïnvloeden van de arbeidsgerichtheid van arbeidsongeschikte werknemers door het verslechteren van de uitkeringspositie zullen niet leiden tot een reïntegratie in het arbeidsproces; eerder lijkt hierdoor een tegengesteld effect gecreëerd te worden: een werknemer, werkend met een handicap, wordt op deze wijze duurder voor een bedrijf en verliest daardoor zijn aantrekkelijkheid voor en mogelijk ook zijn (gedeeltelijke) aanstelling bij dat bedrijf.

Gezondheidsbevorderderende interventies, gericht op de bevordering van de arbeidscapaciteit van (gedeeltelijk) arbeidsongeschikte werknemers, zullen gebaseerd dienen te zijn op een heroriëntatie van WAO-ers met betrekking tot hun handicap, hun ziekte en hun mogelijkheden. Uitgangspunt bij deze heroriëntatie is dat arbeidsongeschikten dienen te leren om zich niet te fixeren op hun beperkingen, maar zich dienen te richten op hun positieve mogelijkheden. In deze vorm van begeleiding kan veel geleerd worden van therapieën, gericht op de voorkoming van chroniciteit en van resocialiseringsactiviteiten, zoals deze binnen de klinische psychologie en de psychiatrie vorm hebben gekregen. Tegelijkertijd dienen bedrijven en organisaties gestimuleerd te worden om te onderzoeken hoe en op welke wijze gedeeltelijk arbeidsgeschikte werknemers in het arbeidsproces heringepast kunnen worden.

Een evaluatie van een meer intensieve begeleidingsmethodiek gericht op de terugkeer van arbeidsongeschikten naar de werkplek en van een begeleiding van de bedrijven om hen te helpen bij de organisatie van een goede inpassing van werknemers met een specifieke beperking laat zien, dat bij voldoende training en scholing van de begeleiders, de extra-kosten die gemaakt 
worden voor een intensieve begeleiding en scholing, in het niet vallen bij de besparing op de uit te keren arbeidsongeschiktheidsgelden ${ }^{30)}$.

Ik heb u laten zien dat de relatie tussen arbeid en gezondheid geen lineaire relatie is; factoren in de arbeidssituatie kunnen onder bepaalde condities leiden tot gezondheids- en welzijnsklachten, maar onder andere condities leiden tot bevordering van gezondheid en welzijn. Dit betekent dat aan gezondheidsbevorderingsprogramma's in bedrijven hoge eisen gesteld dienen te worden. De inhoud van een dergelijk programma dient voor elke organisatie afzonderlijk te worden vastgesteld. Daarbij dient uitgegaan te worden van de specifieke randvoorwaarden in de organisatie en in de afstemming van de eisen die de werksituatie met de capaciteiten en mogelijkheden van nemers. Op basis van de kanttekeningen, zoals ik deze eerder vanmidjemaakt heb, kunnen een zestal voorwaarden beschreven worden waar;ezondheidsprogramma's in bedrijven moeten voldoen ${ }^{31)}$.

1. Interventies dienen gezondheid gerelateerd te zijn en niet ziekte gerelateerd.

Onderzocht dient te worden welke factoren de gezondheid beïnvloeden en verbeteren (in dit geval: het beter kunnen omgaan met stressoren, het bespreekbaar maken van problemen, het beïnvloeden van het besluitvormingsproces bij het leefstijl-interventie-project en het optimaliseren van de resterende arbeidsmogelijkheden van mensen zonder werk).

2. Interventies dienen uit te gaan van een uitgebreide epidemiologische en gedragsdiagnose.

Voorafgaande aan mogelijke interventies dient geanalyseerd te worden welke stressoren in de werksituatie aanwezig zijn, welke factoren in de organisatie, maar ook in de maatschappij (gezondheidszorg, verzekeringsstelsel) bevorderend, danwel belemmerend zijn voor de gezondheid en het welzijn van werknemers. Tegelijkertijd zal ook geanalyseerd dienen te worden welke gedragsfactoren van invloed zijn op de totstandkoming en instandhouding van het gewenste gezondheidsgedrag.

3. Interventies gericht op de bevordering van gezondheid en welzijn, dienen gebaseerd te zijn op een systeem-benadering. Relevante factoren op individueel-, op organisatie- of op maatschappelijk niveau dienen niet geïsoleerd beschouwd te worden, maar binnen de context van elkaar beïnvloedende subsystemen. Beoogde veranderingen van afzon- 
- factoren in de arbeidssituatie die van invloed zijn op het ontstaan en voortduren van verzuim en arbeidsongeschiktheid;

- de relatie tussen arbeid en gezondheid, in het bijzonder met betrekking tot het werken in de gezondheidszorg;

- interventie-onderzoek naar veranderingsprocessen, gericht op de bevordering van gezondheid en welzijn van werknemers.

Dit arbeidsgezondheidkundig onderzoek heeft slechts kans van slagen in een multidisciplinaire setting. Ook de komende jaren zal het arbeidsgezondheidkundig onderzoek gekenmerkt blijven door een combinatie van analytisch en toegepast onderzoek vanuit diverse disciplines. Daarom is de matrix-organisatie van het onderzoek, zoals deze aan de RL vorm heeft gekregen, voor het multidisciplinaire onderzoek op het gebied van arbeid en gezondheid van cruciaal belang.

Aan het einde gekomen van deze openbare les, wil ik de gelegenheid benutten om een kort dankwoord uit te spreken.

Allereerst wil ik het bestuur van de Stichting Wetenschapsbeoefening RL dank zeggen voor de instelling van deze bijzondere leerstoel en voor het in mij gestelde vertrouwen.

Er zijn een aantal mensen die een belangrijke bijdrage geleverd hebben aan mijn wetenschappelijke vorming, die ik apart zou willen noemen.

De aandacht voor het onderzoek naar ziekteverzuim en arbeidsongeschiktheid is in Nederland sterk beïnvloed geweest door het werk van Prof. dr. H. Philipsen. Hans, toen ik hier in Maastricht kwam, heb jij mij op het spoor gezet van ziekteverzuim en arbeidsongeschiktheid. Ik dank jou voor de wijze waarop je in de afgelopen jaren een coachende en enthousiasmerende rol hebt gespeeld.

De psychologie van arbeid en gezondheid is sterk beïnvloed geworden door Prof. dr. Ch.J.J. de Wolff. Zonder zijn activiteiten op dit vakgebied had de psychologie van arbeid en gezondheid nooit zo'n hechte plaats verworven binnen de Nederlandse psychologie. Beste Charles, ik dank jou voor de niet aflatende inspanning die jij voor ons vakgebied verricht hebt.

De leden van de vakgroep Medische Psychologie, die nog steeds mijn thuisbasis is, en in het bijzonder Prof. dr. J.J.C.B. Bremer en Prof. dr. A.P.W.M. Appels, dank ik voor de vrijheid die jullie mij geboden hebben om het onderzoek op het gebied van arbeid en gezondheid vorm te geven. 
deringsproject wel systematisch gebeurd, maar dat ad-hoc invloeden op een veranderingsproject zeer groot zijn en dat de afronding van een veranderingsproces vaak in de lucht hangt. Een planmatige aanpak stopt niet bij het begin van een veranderingsproject, maar alle fasen dienen door een dergelijke aanpak gekenmerkt te worden.

6. Interventies dienen een eindigheid te kennen. Veranderingsprogramma's dienen afgesloten te worden met het vaststellen van de al dan niet bereikte doelen, van de wijze waarop de beoogde veranderingen geimplementeerd zijn en van de wijze waarop deze veranderingen in de bestaande situatie gehandhaafd zullen worden. Zonodig kan de afsluiting van een programma een start zijn voor een nieuw project. Zeker op het gebied van arbeidsomstandigheden, veiligheid, gezondheid en welzijn, zijn in het merendeel van de organisaties een groot aantal onafgemaakte programma's of lopende programma's te onderscheiden.

\section{GEACHTE TOEHOORDERS}

afgelopen drie kwartier heb ik u laten zien dat dezelfde belastingsfac(werkdruk en flexibiliteit) in de werksituatie zowel positieve als negagezondheids- en welzijnseffecten kunnen hebben. Onderzoek zal dienen en zien onder welke condities deze factoren een positief of negatief effect hebben op de gezondheid en het welzijn van werknemers. Tevens is geconstateerd dat een deel van de werknemers-populatie werkt met een hoge arbeidsbelasting, terwijl tegelijkertijd een ander deel van deze populatie niet in staat gesteld wordt te werken. Bij de eerste groep is sprake van structurele overbelasting, terwijl bij de tweede groep sprake is van structurele onderbelasting. Zowel overbelasting als onderbelasting vormt een bedreiging van de gezondheid en het welzijn van werknemers. Om in de komende jaren een betaalbaar en een gezondheidsbevorderend arbeidssysteem te ontwikkelen, zullen onder- en overbelasting meer in evenwicht gebracht dienen te worden.

Zolang de arbeid een centrale plaats inneemt in het leven van de mens, zal ook de bestudering van de relatie tussen arbeid en gezondheid en van de wijze waarop de gezondheid en het welzijn in de arbeid bevorderd kan worden van groot belang blijven.

In de afgelopen jaren heeft het arbeidsgezondheidkundig onderzoek aan de Rijksuniversiteit Limburg vanuit het onderzoeksprogramma "Bedrijfsgezondheidkundige Interventies" zich vooral gericht op: 
derlijke gedragsaspecten hebben een al dan niet gewenste invloed op de context waarbinnen deze gedragsveranderingen plaats zullen vinden, terwijl omgekeerd ook veranderingen in de context leiden tot al dan niet voorspelbare gedragsreacties bij werknemers. Verhoging van de ziekte- en arbeidsongeschiktheidskosten voor bedrijven kan bijvoorbeeld gewenste effecten opleveren met betrekking tot een vergrote verantwoordelijkheid voor de gezondheid, veiligheid en welzijn van de werknemers, maar kan ook leiden tot ongewenste effecten, zoals het niet- of te laat melden van verzuimgevallen, of tot een verscherpte gezondheidsselectie bij intrede in het arbeidsproces en bij het voortzetten van een arbeidsovereenkomst.

Met betrekking tot gezondheidsprogramma's betekent deze constatering dat dit soort programma's niet uitsluitend gericht dienen te zijn op attitude- en gedragsverandering bij de werkenden, maar evenzeer moeten dergelijke programma's gericht zijn op structurele veranderingen in het arbeidsproces. Dit geldt evenzeer voor gezondheidsbevorderingsprogramma's, die gericht zijn op direct arbeidsgerelateerd gedrag: rugtraining, gericht op het beter tillen van zware vrachten, heeft weinig zin als niet tegelijkertijd structureel de tilbelasting beperkt wordt.

4. Interventies dienen uit te gaan van een actieve participatie van betrokken groepen werknemers en van het management. Veel van de mogelijke gezondheidsrelevante veranderingen veronderstellen een verandering in bestaand gedrag van werknemers. Zonder de werknemers een actieve inbreng te geven in de aard van de veranderingen en in de wijze waarop de veranderingen worden doorgevoerd is het ondenkbaar, dat deze veranderingen ook daadwerkelijk succes zullen hebben. Werknemers kunnen belangrijke informatie aandragen met betrekking tot de preventie van overbelasting in de arbeidssituatie. Actieve participatie van werknemers is noodzakelijk voor het welslagen van beoogde veranderingen.

Naast actieve participatie van werknemers, is ook de actieve inzet van het management noodzakelijk. Het management zal naar de organisatie toe duidelijk moeten maken dat zij interventieprogramma's belangrijk en noodzakelijk vindt en dat het management zich daadwerkelijk voor het slagen van deze programma's in zal zetten.

5. Interventies dienen planmatig opgezet te zijn. Een veranderingsstrategie kent een aantal noodzakelijke en afgebakende stappen. Vaak wordt in organisaties gedacht dat veranderingsprocessen planmatig worden aangepakt. In de praktijk blijkt echter vaak dat de start van een veran- 
Natuurlijk is het doen van onderzoek geen eenmanswerk. Zonder de actieve inbreng van de leden van het onderzoeksprogramma Bedrijfsgezondheidkundige Interventies zou dit programma niet hebben kunnen bestaan. Ik dank jullie voor de grote inspanning die jullie op dit terrein gepleegd hebben en de komende jaren zullen blijven hebben.

Het onderwijs is voor mij een bron van inspiratie. Door het geven van onderwijs en het begeleiden van stages wordt ik steeds opnieuw gedwongen om kritisch te blijven staan tegenover de bestaande kennis. Ik dank dan ook de studenten voor hun kritische aandacht en enthousiasme voor het onderwijs op het veld van arbeid en gezondheid.

Tenslotte dank ik mijn familie, zonder de vaak langdurige, maar ook inspirerende discussies met jullie, zou mijn wetenschappelijke nieuwsgierigheid nooit zo geprikkeld zijn geworden.

En natuurlijk ben ik veel dank verschuldigd aan Rose-Marie, Ghislaine, Michiel en Margot, want uiteindelijk zonder jullie permanente sociale steun zou het onmogelijk zijn om mijn werk goed te kunnen blijven doen.

Ik dank u allen voor uw aandacht. 
1. Giele, J. (1981). Een kwaad leven. De arbeidsenquete van 1887. Deel 2: Maastricht, Nijmegen: Link.

2. Ubachs, M. (1976). Een eeuw modern kapitalisme. De Regouts/Leed en strijd van Maastrichts proletariaat. Nijmegen: Link.

3. Centraal Bureau voor de Statistiek. (1994). 1899-1994. Vijfennegentig jaren statistiek in tijdreeksen. Den Haag: SDU.

4. Schröer, C.A.P. (1993). Ziekteverzuim wegens overspanning. Rijksuniversiteit Limburg, dissertatie.

5. Horst, F. van der. (1988). Gezondheid en niet werken. Rijksuniversiteit Limburg, dissertatie.

6. Horst, F.G.E.M. van der, Nijhuis, F.J.N. \& J.W.M. Muris. (1993). Morbidity in work-incapacitated and unemployed men. Scandinavian Journal of Work, Environment and Health, 19, 168-174.

7. Warr, P., Jackson, P. \& M.H. Banks. (1988). Unemployment and mental health. Journal of Social Issues, 47-68.

8. Viinamaki, H., Koskela, K., Niskanen, L., Arnkill, R. \& J. Tikkanen. (1993). Unemployment and mental well-being: a factory closure study in Finland. Acta Psychiatrica Scandinavia, 429-433.

9. Martikainen, P.T. (1990). Unemployment and mortality among Finnish men, 1981-1985. British Medical Journal, 407-411.

10. Sogaard, J. (1992). Economic critique of the economic change model of mortality. Social Science Medicine, 947-957.

11. Wilson, S.H. \& G.M. Walker. (1993). Unemployment and Health: A review. Public Health, 153-162.

12. Algera, M. \& F. Nijhuis. Unemployed men: are they in poorer health. (in prep).

13. Zie ook: Leeflang, R.L.I., Klein Hesselink, D.J. \& I.P. Spruit. (1992). Health effects of unemployment II. Men and Women. Social Science and Medicine, 351-363. 
14. Horst, F. van der, Nijhuis, F., Muris, J., Philipsen, H. \& Grinten v.d., R. (1992). Causality in the relation between health and long-term unemployment. In: Verhaar, C.H.A. \& L.G. Jansma et al. (eds., On the mysteries of unemployment, 225-252.

15. Zie bijv. Blackburn, J.D. (ed.). (1991). Time-based competition. The next battleground in American manufacturing. Homewood (III.): Irwin.

16. Shingo, S. (1985). Study of Toyota production system from industrial engineering view point. Tokyo: Japan Management Association.

17. Diekstra, R.F.W., Heus, P. de, Schouten, M.H. \& Houtman, I.L.D. (1994). Werken onder druk. Een onderzoek naar omvang en factoren van werkstress in Nederland. Den Haag: VUGA.

18. Jonge, J. de, Janssen, P. \& A. Landeweerd. (1994). Effecten van werkdruk, autonomie en sociale ondersteuning op de werkbeleving van verplegenden en verzorgenden. Verpleegkunde, 7 (4), 17-27.

19. Uehata, T. (1991). Karoshi due to occupational stress-related cardiovascular injuries among middle-aged workers in Japan. J. Science of Labour, 67 (1), 20-28.

20. Karasek, R. \& T. Theorell. (1990). Healty work: stress, productivity and the reconstruction of working life. New York: Basic Books.

21. Rotch, W. (1993). Management control systems: one view of components and their interdependence. British Journal of Management, 1991-203.

22. Lendfers, M.L. \& F. Nijhuis. (1989). Flexibilisering van de arbeid en gezondheidseffecten. Den Haag, Organisatie voor Strategisch Arbeidsmarktonderzoek.

23. Atkinson, J. (1988). Recent changes in internal labour market structure in the UK. In: Buitelaar, W. (ed.), Technology and work: Labour studies in England, Germany and the Netherlands. Aldershof: Avebury, 133-149.

24. Martens, M.F.J., Boxtel van, M.P.J., Nijhuis, F.J.N. \& J.A. Knottnerus. (1995). Flexibele arbeidsomstandigheden en gezondheidsklachten. Gedrag en Organisatie, 8, 1, 50-60.

25. Zie ook: Hall, D.T. \& V.A. Parker. (1993). The role of workplace flexibility in managing diversity. Organizational Dynamics, 5-18. 
26. Nijhuis, F., Lendfers, M.L. \& R. Bullinga (1990). Health effects of flexibilization of work. News from EFPPA, Vol.IV-4.

27. Zie ook: Cordey, J., Sevastos, P., Mueller, W. \& S. Porker. (1993). Correlates of employee attitudes toward functional flexibility. Human Relations, 705-723.

28. De Korte, A.W. \& Bolweg, J.F. (1994). De Nieuwe werknemer?! Een verkenning naar veranderingen in werknemerswensen en de management consequenties daarvan. Assen: Van Gorcum.

29. Nijhuis, F., Lendfers, M.L., Jong, A. de \& Janssen, P. (1994). Stressrelated interventions in construction work. Meeting of the working group on Assessing the Benefits of Stress Prevention. Barcelona.

30. Maarse, H., Nijhuis, F. \& E. Molin. (1994). Arbeidskundige begeleiding als middel tot beperking van arbeidsongeschiktheid. Tijdschrift voor Bedrijfs- en Verzekeringsgeneeskunde, 1, 2, 71-76.

31. Zie ook: Levi, L. (1994). Work, worker and well-being: an overview. Work and Stress, 8 (2), 79-83. 